\section{PENELITIAN PENGARUH PEMBUNGKUS PLASTIK TERHADAP KUALITAS TEMPE KEDELE DENGAN VARIASI JENIS PLASTIK DAN LOBANG PLASTIK}

\author{
Oleh : C. Yuwono Sumasto, Sri Budiasih B.Sc
}

\section{ABSTRACK}

This aim of research is to find out the plastic pakage effects the quality soy tempeh wich use comparison leaves package. The objective of research is effect of kinds and holes of plastic for quality tempeh. it has two variables these are kinds of plastics each polypropylene $(P P)$ and polyethylene $(P E)$ with hole variation of plastic are 20,25 and 30 each size number was $12 \mathrm{~cm} \times 24 \mathrm{~cm}$. Result of the research shown kinds and holes of plastic is not to take effect water and ash contain in tempeh. Testing laboratory result shown, water and ash contain is not to take effect by variable of the object research whereas protein contain in soy tempeh with plastic package is not fulfills specification SII 0271-80 "Kualitas Tempe Kedele" $\min 20 \%$, whereas protein contain of tempeh with leave package is result $24,281 \%$.

\section{INTISARI}

Penelitian ini dimaksudkan untuk mengetahui pengaruh pembungkus plastik terhadap kualitas tempe kedele dibandingkan dengan tempe kedele bungkus daun, dengan variasi jenis plastik dan jumlah lobang plastik. Variabel yang dipakai adalah: Jenis plastik dua buah yaitu jenis Poli etilen dan jenis Poli Propilen dengan ukuran plastik $12 \mathrm{~cm} \times 24 \mathrm{~cm}$ sedangkan variasi lobang plastik yang dipakai ialah lobang 20,25 dan 30 tiap permukaan plastik.

Dari hasil penelitian diketahui bahwajenis plastik dan banyaknya lobang plastik tidak mempengaruhi kadar air dan kadar abu. Hasil uji laboratorium menunjukkan bahwa kadar air dan kadar abu tidak terpengaruh oleh variabel yang diteliti sedangkan kadar protein tempe kedele dengan pembungkus plastik ternyata tidak memenuhi SII 0271 - 80 "Kualitas Tempe Kedele" minimal 20\%. sedangkan tempe dengan pembungkus daun kadar proteinnya mencapai $24,281 \%$

\section{PENDAHULUAN}

Perkembangan plastik dewasa ini sudah berkembang sangat pesat dan banyak digunakan untuk berbagai keperluan rumah tangga dan perdagangan termasuk diantaranya plastik untuk kemasan. 4)

Plastik kemas itu sendiri masih banyak jenis dan fungsinya dimasyarakat, salah satu yang banyak digunakan adalah plastik kantong untuk pembungkus makanan yang banyak beredar dipasaran, baik yang food grade maupun untuk penggunaan umum dalam bentuk yang bermacam macam dan bervariasi untuk menarik selera konsumen, disamping harganya yang cukup murah dan dapat diproduksi secara massal sebagai pengganti pembungkus daun. 4)

Dewasa ini kemasan plastik yang beredar dipasaran ada bermacam-macam jenis bahan yang digunakan antara lain : Polyethylene, Polypropylene, Polyvynyl
C lilanide dan masih banyak lagi.

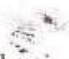

Iempe merupakan sumber protein nabati yang murah dan mudah didapa Hain Hikconsimsi sehingga banyak sekali beredar dan dikonsumsi oleh masyarakat liniai memenuhi kebutuhan akan protein.5 Saat ini tempe banyak ditemui Himianyakak pasaran dengan menggunakan pembungkus dari plastik sebagai HiHeEanti pembungkus dari daun, tetapi sejauh ini belum didapat keterangan tentang fengaruih pembungkus plastik terhadap kualitas tempe kedele baik secara fisik

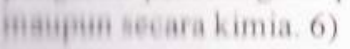

Аамра saat ini belum ada keterangan mengenai berbagai pembungkus tempe Hetaik plasilk pembungkus tempe ekdele terhadap kualitas tempe mengingat tempe adalah Hitak aнan yang sangat merakyat dan banyak dikonsumsi.

\section{MAIIAN BAN METODA}

\section{HAHIAN}

Hahan yang digunakan dalam penelitian ini adalah :

\section{Kedele}

Mastik pembungkus

Char atau ragi tempe

Alai yaie dipergunakan

Seperangkat alat untuk memasak kedele

Alat pelobang plastik

Alat-alat uji laboratorium

\section{AI IODE}

Dalam melaksanakan penelitian ini bahan berupa kedele dimasak menjadi heiengah matang dan dihilangkan kulitnya kemudian dibuat menjadi bakalan tempe demean menggunakan prosedur yang biasa dipergunakan oleh para perajin/ pengusaha tempe yang ada di DI Yogyakarta.

Hakalan tempe kemudian dimasukkan dalam plastik yang telah diberi lobang dengain variasi yang dipakai yaitu jenis plastik Polietylen (PE) dan jenis plastik PoliFrepylen (PP) dengan variasi lobang 20,25 dan 30 lobang setiap permukaan plastik pembiangkus (ukuran $12 \mathrm{~cm} \times 24 \mathrm{~cm}$ ) dan sebagai kontrol digunakan pembungkus dait daun pisang kemudian diinkubasikan selama q 2 hari. Setelah tempe jadi dalam Wakii serempak dilakukan pengujian kadar air, kadar abu dan kadar protein diliaberatorium dengan prosedur analisa kimia untuk bahan makanan dan pertanian denean pembanding tempe yang dibungkus dengan menggunakan daun.

Vei XII No, 25 Th. 1997/1998 
ANALISA

Analisa dari hasil pengujian dilaboratorium dilakukan dengan menggunakan perhitungan statistik metode ANOVA

\section{HASIL PENELITIAN DAN PEMBAHASAN}

Hasil uji laboratorium dari kadar air, kadar abu dan kadar protein dari masingmasing variabel dapat dilihat pada tabel berikut :

Tabel 1 : Data hasil uji Kadar air (\%).

\begin{tabular}{|c|c|c|c|}
\hline \multirow{2}{*}{ Jenis Plastik } & \multicolumn{3}{|c|}{ Jumlah Lobang } \\
\cline { 2 - 4 } & 20 & 25 & 30 \\
\hline Poli Etilen (PE) & 60,23 & 63,01 & 65,95 \\
& 60,83 & 65,34 & 67,23 \\
& 66,67 & 63,27 & 64,47 \\
& 63,27 & 66,94 & 64,54 \\
\hline Poli Propilen (PP) & 64,31 & 63,45 & 65,76 \\
& 64,01 & 64,56 & 64,88 \\
& 63,74 & 65,71 & 64,68 \\
& 65,27 & 63,06 & 65,24 \\
\hline Kontrol & 63,23 & & \\
\hline
\end{tabular}

Tabel 2 : Data hasil uji Kadar abu (\%).

\begin{tabular}{|c|c|c|c|}
\hline \multirow{2}{*}{ Jenis Plastik } & \multicolumn{3}{|c|}{ Jumlah Lobang } \\
\cline { 2 - 4 } & 20 & 25 & 30 \\
\hline Poli Etilen (PE) & 1,318 & 1,495 & 1,403 \\
& 1,452 & 1,524 & 1,305 \\
& 1,483 & 1,504 & 1,329 \\
& 1,482 & 1,458 & 1,352 \\
\hline Poli Propilen (PP) & 1,397 & 1,443 & 1,500 \\
& 1,278 & 1,075 & 1,526 \\
& 1,457 & 1,462 & 1,419 \\
& 1,477 & 1,482 & 1,497 \\
\hline Kontrol & 1,457 & & \\
\hline
\end{tabular}

Taabel 3 : Data hasil uji Kadar protein $(\% \mathrm{~N})$

\begin{tabular}{|c|c|c|c|c|c|c|c|}
\hline \multirow{2}{*}{\multicolumn{3}{|c|}{ Jenis Plastik }} & \multicolumn{5}{|c|}{ Jumlah Lobang } \\
\hline & & & 20 & \multicolumn{2}{|c|}{25} & \multicolumn{2}{|c|}{30} \\
\hline \multicolumn{3}{|c|}{ l'oli Etilen (PE) } & \multirow{2}{*}{$\begin{array}{l}10,479 \\
10,819\end{array}$} & \multicolumn{2}{|r|}{13,268} & \multicolumn{2}{|c|}{10,124} \\
\hline & 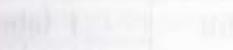 & & & \multirow{2}{*}{\multicolumn{2}{|c|}{$\begin{array}{c}8,427 \\
16,406\end{array}$}} & \multirow{2}{*}{\multicolumn{2}{|c|}{$\begin{array}{l}10,240 \\
14,153\end{array}$}} \\
\hline & 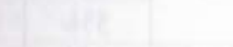 & & 15,004 & & & & \\
\hline & $y_{1}$ & & 18,099 & \multicolumn{2}{|r|}{16,649} & \multicolumn{2}{|c|}{17,055} \\
\hline \multirow{4}{*}{\multicolumn{3}{|c|}{ Poli Propilen (PP) }} & 10,690 & \multicolumn{2}{|r|}{13,076} & \multicolumn{2}{|c|}{10,045} \\
\hline & & & \multirow{2}{*}{$\begin{array}{l}11,804 \\
16,642\end{array}$} & \multicolumn{2}{|r|}{7,348} & \multicolumn{2}{|c|}{13,674} \\
\hline & & & & & 18,304 & \multirow{2}{*}{\multicolumn{2}{|c|}{$\begin{array}{l}16,550 \\
20,117 \\
\end{array}$}} \\
\hline & & & 17,779 & \multicolumn{2}{|r|}{17,225} & & \\
\hline \multicolumn{3}{|c|}{ Kontrol } & \multicolumn{3}{|l|}{24,281} & & \\
\hline \multicolumn{8}{|c|}{ Tabel 4: Analisa of Variance Kadar air } \\
\hline \multirow[t]{2}{*}{ He } & \multirow[t]{2}{*}{ Sumber Variasi } & $\mathrm{dk}$ & \multirow[t]{2}{*}{$\mathrm{jk}$} & \multirow[t]{2}{*}{ rjk } & \multirow[t]{2}{*}{ F hit } & \multicolumn{2}{|c|}{ F tabel } \\
\hline & & & & & & $5 \%$ & $1 \%$ \\
\hline 1 & Jenis Plastik & 1 & 0,8289 & 0,8289 & 0,2927 & 4,45 & - \\
\hline 1. & L obang Plastik & 2 & 15,9473 & 7,9736 & 2,8165 & 3,59 & - \\
\hline t. & $119 \times 1 P$ & 2 & 7,6414 & 3,8207 & 1,3496 & 3,59 & - \\
\hline 1 & Inor & 17 & 70,0464 & 4,1203 & & & - \\
\hline 1 & Total & 22 & 66,8226 & & & & - \\
\hline
\end{tabular}

(Cant analisa tersebut diatas nilai $\mathrm{F}$ hitung $<$ F Tabel, sehingga tidak ada pengaruh (iani variasi jenis plastik dan lobang plastik pada kadar air tempe kedele>.

Tabel 5 : Analisa of Variance Kadar abu

\begin{tabular}{|c|c|c|c|c|c|c|c|}
\hline \multirow[t]{2}{*}{ Ne } & \multirow[t]{2}{*}{ Number Variasi } & \multirow[t]{2}{*}{$\mathrm{dk}$} & \multirow[t]{2}{*}{ jk } & \multirow[t]{2}{*}{ rjk } & \multirow[t]{2}{*}{ F hit } & \multicolumn{2}{|c|}{ F tabel } \\
\hline & & & & & & $5 \%$ & $1 \%$ \\
\hline 1 & Jenis Plastik & 1 & 0,0004 & 0,0004 & 0,0317 & 4,45 & 8,40 \\
\hline 1 & L obang Plastik & 2 & 0,0010 & 0,0005 & 0,0397 & 3,59 & 6,11 \\
\hline 1. & II $\times$ LP & 2 & 0,0734 & 0,0367 & 2,9124 & 3,59 & 6,11 \\
\hline 1 & Irror & 17 & 0,2434 & 0,0143 & & & - \\
\hline 4 & Iotal & 22 & 0,2448 & & & & - \\
\hline
\end{tabular}

Chan analisa tersebut diatas nilai F Hitung $<$ F Tabel, sehingga tidak ada pengaruh 
dari variasi jenis plastik dan lobang plastik pada kadar abu tempe kedele.

Tabel 6: Analisa of Variance Kadar Protein

\begin{tabular}{|l|l|c|c|c|c|c|c|}
\hline No & Sumber Variasi & $\mathrm{dk}$ & $\mathrm{jk}$ & rjk & F hit & \multicolumn{2}{|c|}{$\mathrm{F}$ tabel } \\
\cline { 6 - 8 } & & & & & & $5 \%$ & $1 \%$ \\
\hline 1. & Jenis Plastik & 1 & 6,7151 & 6,7151 & 2,1161 & 4,28 & 7,88 \\
2. & Lobang Plastik & 2 & 0,9583 & 0,4791 & 0,1569 & 3,42 & 5,66 \\
3. & JP X LP & 2 & 3,6199 & 1,8099 & 0,5703 & 3,42 & 5,66 \\
4. & Error & 17 & 291,4632 & 17,144 & & & - \\
5. & Total & 22 & 299,1366 & & & & - \\
\hline
\end{tabular}

Dari analisa tersebut diatas, nilai F Hitung $<$ F Tabel sehingga tidak ada pengaruh dari variasi jenis plastik dan lobang plastik pada kadar protein tempe kedele $>$.

\section{PEMBAHASAN}

Dari uji laboratorium dan perhitungan statistik bahwa Kadar air, kadar abu dan kadar protein tempe kedele semakin besar dengan semakin banyaknya lobang yang ada pada permukaan plastik hal ini dikarenakan semakin banyaknya permukaan tempe yang berfermentasi oleh ragai karena udara disekitarnya, meskipun demikian bila dibandingkan tempe dengan menggunakan pembungkus daun kadar proteinnya menunjukkan perbedaan yang cukup mencolok.

\section{KESIMPULAN}

Dari hasil penelitian pengaruh pembungkus plastik terhadap kualitas tempe kedele didapatkan kesimpulan sebagai berikut :

1. Kadar Air Tempe Kedele

Untuk variasi jenis plastik dan lobang plastik tidak mempengaruhi kadar air tempe kedele.

2. Kadar Abu Tempe Kedele.

Kadar abu tempe kedele tidak dipengaruhi oleh variasi jenis plastik dan lobang plastik.

3. Kadar Protein Tempe Kedele

Variasi lobang plastik dan jenis plastik tidak mempengaruhi kadar protein tempe kedele.

4. Hasil perhitungan T Test untuk membandingkan tempe dengan pembungkus plastik dan tempe dengan pembungkus daun didapatkan hasil sebagai berikut : l lidak ada perbedaan nyata kadar air dan kadar abu tempe kedele yang dibungkus detigin plastik dan yang dibungkus dengan daun.

Aili perbedaan yang sangat nyata kadar protein pada tempe kedele yang dilinisk us dengan plastik dan tempe yang dibungkus dengan daun, tempe kedele yaie dibungkus dengan daun lebih besar kadar proteinnya (memenuhi SII 0271iii) iedangkan tempe kedele yang dibungkus dengan plastik tidak memenuhi ayarat Sil.

\section{DAFIARPUSTAKA}

I Chepartemen Perindustrian, Standar Industri Indonesia 0271-80 "Kualitas Tempe Kedele"

1. Hamei Sudarmadi, Bambang Haryono, Sukadi : "Produser Analisa untuk Bahan Makanan dan Pertanian", Liberty Yogyakarta, 1981.

I thehemi Soedigdo, P. Soedigdo: Pengantar cara statistika kimia, ITB Bandung, 1077.

I. Hutidia Nurti Drs, Inggriani BSc: Migrasi Additive dari pengemas plastik kedalam heibagai jenis makanan, Proyek Penelitian dan Pengembangan Industri Hasil Dettanian, 1985-1986.

I Iifien Sayekti Sesantiningsih: Usaha-usaha untuk memperpanjang daya simpan tempe kedele.

A. William Shurtleff, Akiko Aoyogi: The Book of Tempeh a super soy food Indoneuia, Ilarper \& Row, Publishers New York, Hegers Town Sanfransisco, London, 1979 